\title{
RITO E TESTEMUNHO NA PRODUÇÃO DA VERDADE JURÍDICA
}

Catarina G. Paes Henriques ${ }^{1}$ Sandro José da Silva ${ }^{2}$

RITE AND TESTIMONY IN THE PRODUCTION OF THE
LEGAL TRUTH

RESUMO: Este artigo se dedica a descrever as peculiaridades dos ritos judiciários contidos na figura do testemunho. Mediante o método etnográfico nos tribunais, o presente artigo nos revelará peculiaridades que vão além dos manuais de processo. O estudo foi realizado em 3 Varas Criminais de Vitória/Espírito Santo no ano de 2015. Durante o estudo foram registrados os dados de interesse da pesquisa por meio de diário de campo.

Palavras-chave: Direito. Testemunho. Verdade Jurídica. Saber-Poder.

\begin{abstract}
This article is dedicated to describing the peculiarities of the judicial rites contained in the figure of the testimony. Through the ethnographic method in the courts, this article will reveal peculiarities that go beyond the process manuals. The study was carried out in 3 Criminal Courts of Vitoria / Espírito Santo in 2015. During the study were registered the data of interest of the research through field diary.
\end{abstract}

Keywords: Law. Testimony. Legal truth. PowerKnowledge.

\footnotetext{
${ }^{1}$ Doutoranda em Psicologia pela Universidade Federal do Espírito Santo, mestra em Direito pela Universidade Federal do Espírito Santo e graduada em Direito pela Universidade Católica do Salvador. Bolsista CAPES.

2 Doutor em Antropologia pela Universidade Federal Fluminense, mestre em Antropologia Social pela Universidade Estadual de Campinas e Bacharel em Ciências Sociais pela Universidade Federal do Espírito Santo. Professor Adjunto na Universidade Federal do Espírito Santo na Graduação em Ciências Sociais e nos Programas de Pós-Graduacão em Ciências Sociais e Direito. Membro do Comitê de Quilombos da Associação Brasileira de Antropologia.
} 


\section{INTRODUÇÃO}

O testemunho é visto como uma fase isolada, onde uma pessoa dá, segundo a visão corrente, um depoimento do que recorda dos fatos. Conclui-se que tal ação faz parte de um sistema muito mais complexo, que é integrado de regras vão além das vontades instituídas como a do juiz e mesmo da testemunha, pois é anterior estes, e com as quais eles produzem novas modalidades de interação, regimes de verdade e reprodução da "verdade jurídica".

A ritualística processual exterioriza, representa e classifica os objetos e os seres, de forma a agir sobre o real por meio da sua representação simbólica. Assim como em outros campos, há uma necessidade de organizar o plano da vida advinda da própria estratégia humana, que permite a cada cultura ordenar e organizar esse "real" da forma que the convém. Neste sentido, a imagem que se tem do direito é uma organização normativa, quando se trata, de fato, de arranjos possíveis de elementos mais e menos formais, retirados de um arcabouço formal, as leis, e sua contextualização, a vida imediata.

Os atores que estão no campo do direito (BOURDIEU, 1989) lidam, por isso, não apenas com normas formais, mas com um universo de representações disponíveis na sociedade que visa incutir respeito (GARAPON, 1997). Neste sentido, trata-se de reconhecer a arbitrariedade de tais normas não apenas porque elas foram construídas socialmente, mas porque apresentam variações segundo se observe eixos como classe, raça e gênero no processo.

Michel Misse (2010, p. 16) argumenta que o crime não é algo natural das ações humanas, mas o resultado da "interação social em que uma parte acusa moralmente a conduta da outra e, sendo bem-sucedida, obtém a institucionalização daquele curso de ação, idealmente tipificado como 'crime', nos códigos penais". Na presente proposta, vamos nos deter no cotidiano da produção dessas condutas que estão autorizadas a julgar e condenar e descrever algumas minúcias que não se encontram nos referidos códigos para tal.

Roberto Kant de Lima (1997) sugere que não é possível fazer uma análise desse sistema de produção de verdades tomando-o em sua existência ímpar, mas comparando-o 
como outros sistemas, como o norte-americano por exemplo. Como se sabe, o regime de verdade do criminal norte-americano, "repousa sobre a ideia de que a verdade é fruto de uma decisão consensual sistematicamente negociada". Neste sentido,

\begin{abstract}
a verdade pública produzida para administrar conflitos é, explicitamente, fruto (a) de uma negociação patrocinada pelo District Attorney Office (promotoria) - uma barganha em que cada uma das partes desiste de sua verdade para compor uma terceira versão satisfatória para todos - ou (b) de uma negociação no âmbito do judiciário, entre os jurados, árbitros selecionados pelas partes para decidir qual a verdade que vão dizer ao público, depois de presenciarem a exposição dos fatos admitidos em juízo - seu verdict (vere dictum) (LIMA, 1997).
\end{abstract}

No caso aqui analisado, as normas e a própria ideia de direito e justiça não estão dadas e garantidas apenas por um conjunto de códigos, mas devem ser atualizadas repetidamente mediante contextos de interação e ritualísticas inscritas em falas, atos e mesmo na arquitetura palaciana dos tribunais que se distribui em diferentes espaços.

A tônica desse texto surgiu quando da recuperação de algumas memórias sobre a atividade profissional perante algumas Varas. Os eventos antes presenciados se transformaram em uma nova modalidade de observação a partir do estranhamento etnográfico com os dados coletados na atualidade. Pôde-se, então, realizar uma comparação e reforçar alguns pontos argumentativos do artigo.

Este artigo, então, se dedica a descrever as peculiaridades dos ritos judiciários contidos na figura do testemunho mediante o método etnográfico nos tribunais. Este estudo foi realizado em 3 Varas Criminais de Vitória/Espírito Santo no ano de 2015 e nos revelará peculiaridades que vão além dos manuais de processo. Durante o estudo foram registrados os dados de interesse da pesquisa por meio de diário de campo.

O presente artigo se fundamenta na etnografia como modo de obtenção de dados a partir de alguns pressupostos tais como a presença do pesquisador nos contextos da pesquisa, o estranhamento das situações sociais "naturalizadas" e a busca dos significados construídos pelos sujeitos em suas ações. Os sujeitos estão presos em teias de significados que conferem sentido às suas ações e é a "descrição densa" dos acontecimentos que faz com que estes não sejam meros acontecimentos sem importância (GEERTZ, 2014).

O trabalho do etnógrafo é, neste sentido, inserir-se nos contextos nos quais tais significados são produzidos e descrevê-los para uma audiência mais ampla. Tais significados 
são públicos, ou seja, são o resultado das interações sociais, mas, no entanto, seus significados não são percebidos como tais senão pelos sujeitos envolvidos na sua produção.

Ao eleger os rituais como recorte da observação, estão em jogo a descrição dos artifícios sociais mais significativos no campo do direito que alia o formalismo das normas à ritualística de construção pública de sua autoridade. Baseando-nos em Victor Turner (1980), percebemos que o testemunho é uma das fases do ritual de produção da verdade.

Para este autor, existe uma divisão do tempo ritual que define posições de passagem entre estágios: desagregação - em nosso caso, uma pessoa comum se torna "testemunha", - comunitas - em nossa análise, a pessoa se converte em uma parte de um processo mais longo, ou seja, um eminente desconhecido-, e, por fim, a reagregação - onde a testemunha volta a ser um cidadão que cumpriu seu dever com a verdade e com a manutenção da ordem.

Como o ritual de produção da verdade se fundamenta em parte no testemunho, decorre que ele se torna parte da cultura jurídica, em torno da qual se ergue a legitimidade e eficácia pública da Justiça. Como V. Turner (1980, p. 122) recomenda, a observação do aspecto da "transição" nos rituais é fundamental na [re]produção da sociedade: a dúvida é transformada em verdade, o juiz se re-faz autoridade, o réu se vê envolto na reprodução de sua condição criminal e a testemunha é a possibilidade de uma verdade específica ser evidenciada, mas dentro de determinados preceitos ritualizados.

\section{RITUAL JUDICIÁRIO}

Para entrar no Palácio da Justiça, é necessário percorrer escadas longas com vários degraus e passar por uma grande porta com seguranças uniformizados e armados que trazem em letras garrafais escritas na tipologia romana, a palavra "FÓRUM CRIMINAL". Não raro, a inscrição homenageia algum ministro ou desembargador venerado pela comunidade de juristas. Quem chega ao fórum tem que subir, não somente para chegar ao patamar de onde se realiza a justiça, mas para ascender espiritualmente ao patamar da verdade. Alguns fóruns mais contemporâneos inseriram espelhos, mas ainda faz bastante sucesso as colunas romanas, estátuas ou até mesmo o letreiro em latim "FORVM". 
A monumentalidade esmaga o comum, o ordinário e o impuro, mas é isso que dá sentido à sua existência. Sem o reconhecimento da sua grandiosidade e de tudo que um tribunal representa, ao menos para os que nele habitam, ele nada seria.

Cada vez mais longe do mundo profano, o caminho continua com a entrada na sala de audiências, pela chamada do código, o número do processo que identifica as partes. Deve-se entrar respeitando a ordem, seguindo como um cortejo e aguardar o início da sessão. Cada qual com o seu papel; cada qual em seu lugar. A porta de entrada é o ponto mais distante do juiz, que faz o trânsito entre o mundo profano e o dos especialistas. O juiz senta-se ao centro, em cadeira que indica a sua posição superior. O promotor, ao lado do juiz e o advogado de defesa, perto do acusado, na mesa defronte ao juiz. A liturgia judiciária impede que se escape dessa determinação.

Elementar ao processo, a denominação "partes" sugere como cada um deve agir; trata-se de um exemplo da nomeação das coisas e utensílios jurídicos, uma objetivação que reduz as pessoas ao que elas representam social e historicamente, identificando os atores e distribuindo seus papéis (SILVA, 2013), ao esquematizar as linhas que eles devem manter segundo uma fachada esperada. O ritual presume, assim, a existência da identidade e da diferença, que une os atores e distribui os papéis.

Em uma determinada vara, o magistrado dizia chegar cedo porque gostava de se preparar e que "em mais de 10 anos de magistratura nunca havia se atrasado". Entrava na sala bem vestido, de cabelo arrumado, de óculos e de toga. Antes de ser titular naquela vara, os funcionários entravam e saíam livremente da sala, a fim de resolverem questões atinentes às suas funções ou mesmo assistirem às audiências.

As entradas e saídas, entretanto, foram reprovadas de pronto pelo magistrado, levando-o a afirmar que "com ele não tem bagunça" e que a sala de audiência não é "casa da mãe Joana". Proibiu a entrada de qualquer pessoa durante as audiências, inclusive a mando do MP, ordenando o trancamento da porta enquanto fosse da sua vontade. Além de absorver aquela identidade ritualística da audiência, queria ter o poder sobre tudo e sobre todos.

Esse evento nos remete à passagem de Garapon (1997) quando afirma que o processo, que é de ordem ritual, não pode ser interrompido por nada nem ninguém. A 
"juizite", segundo Lopes (2010), vem acompanhada pelo desejo de poder e onde houver juízes, advogados, promotores ou qualquer outro título que seja considerado um troféu, então haverá "pompa e circunstância".

Após os juízes, promotores, defensores e escrivães trocarem lanches e conversarem sobre os mais diversos temas, os trabalhos na sala de audiência começam pela oitiva das testemunhas. Faz parte da práxis o magistrado informar à testemunha que ela está sob o compromisso de dizer somente a verdade e a testemunha responder "sim, senhor (a)".

Em uma determinada audiência, o magistrado advertiu de forma ameaçadora todas as testemunhas que prestaram o compromisso. Disse, olhando por cima das lentes dos óculos, que a testemunha tinha que dizer a verdade, frisando que "poderia ser presa por qualquer coisa errada que dissesse", enfatizando a palavra "presa". Neste caso, devido às manobras protetoras de respeito e polidez (GOFFMAN, 2011), a testemunha também afirmou o mesmo "sim, senhor (a)". Trata-se de um exemplo de como os "juramentos de promessa e maldição" (FOUCAULT, 2002, p. 33), previstos desde 427 a.C. na tragédia grega Édipo Rei, ainda geram efeitos nos dias de hoje.

O formalismo mágico dos rituais impregnado no mundo jurídico, como o juramento e a leitura das conclusões, enaltece a autoridade do ato de interpretação e reafirma a necessidade de se continuar a tratar o direito como hermeticamente fechado. Esse ritual do juramento realiza o contato tão temido com o sagrado e quem jura, segundo Garapon (1997), dá a sua pessoa como garantia à divindade em troca do reconhecimento da verdade dos seus propósitos: uma automaldição condicional.

Historicamente, o juramento só pode ser concebido numa sociedade em que tal fé seja compartilhada por todos, pois a confiança deve partir da testemunha, que só pode temer as sanções de um deus em que acredita; e deve partir do juiz, porque só pode confiar num juramento dirigido a um ser no qual crê. O ato de jurar, apesar do passar do tempo, ainda guarda em si um pouco do ato de fé; não mais fé em um deus, mas fé no modelo, no procedimento, no ritual em si mesmo (GARAPON, 1997).

A prática não esconde o quão o procedimento é levado a sério, quando juízes ameaçam testemunhas, incutindo seriedade e necessidade ao rito, e as testemunhas se mostram (pelo menos em aparentemente) aptas e dispostas a corroborá-lo. Atualmente 
não se jura mais perante Deus, pois a esperança agora habita a palavra e o compromisso que, se não respeitados, desencadeiam uma intervenção mais dura e mais violenta por parte da justiça. Trata-se, pois, de uma dívida advinda da sua palavra, de uma consciência social, pois prolatada publicamente (GARAPON, 1997).

Ultrapassada a fase dos juramentos, os questionamentos se iniciam. Num caso concreto, a promotoria perguntou se a testemunha se recordava e se reconhecia os acusados como as pessoas detidas, a testemunha então afirmou "sim, reconheço esses indivíduos". No momento da transcrição para a ata, o juiz dita para o escrivão a palavra "elementos" e não "indivíduos", como falado pela testemunha. Isso poderia influenciar posteriormente o ato de decidir do magistrado, pois "elementos" aparentam mais culpa do que "indivíduos".

O magistrado passa então a interrogar a testemunha, interrompendo seu relato diversas vezes a fim de traduzi-lo para uma linguagem considerada mais adequada a preencher um documento público. Para retomar a oitiva, o juiz se utiliza da expressão, "sim, e aí?", demonstrando certa ansiedade em continuar o rito. Após a quarta retomada dos relatos por meio da expressão "sim, e aí?", a testemunha se mostrou impaciente e seus relatos ficaram "truncados", a contragosto do magistrado.

Pode-se inferir da observação da oitiva de testemunhas que, quando as respostas não agradam o magistrado, a necessidade de se saber a "verdade" o faz repetir a mesma pergunta mais de uma vez. Noutro caso concreto, o juiz parecia querer confirmar algo que estava escrito nos autos e precisava que a resposta da testemunha fosse afirmativa, então perguntou três vezes seguidas se a arma estava escondida no carro. Para Goffman (2011), essas interrupções e faltas de atenção podem comunicar desrespeito, a não ser que esse desrespeito implicado possa ser aceito por uma parte da relação, como é o caso do réu e da testemunha que, na relação de poder, são os dominados no jogo de produção da verdade. De outra parte, pode se tratar de um sinal de exteriorização hierárquica de quem está acima e não pode ouvir corretamente, o juiz.

Ainda em relação aos questionamentos, observamos em determinada vara criminal que o promotor perguntou a uma testemunha se os transeuntes do local do crime em questão ficaram assustados com o disparo. Durante o relato da testemunha, o 
representante do Ministério Público fazia sinais afirmativos com a cabeça, no sentido de que estava entendendo e que a testemunha estava no caminho certo, respondendo de acordo com o que ele queria ouvir.

Nesse caso, se houve disparo de arma de fogo, é provável que possa ter causado susto nos transeuntes, mas a aparente intenção do promotor era fomentar a relevância do crime cometido pelo réu, deixando incontestável que as pessoas se assustaram, o que sublinha a gravidade. Após a oitiva, o juiz ditou para o escrivão a fala da testemunha enfatizando que os transeuntes se assustaram com os "vários disparos". A referida testemunha não utilizou a expressão "vários disparos" na primeira versão dos fatos relatados, mas tal expressão, que passou até mesmo a constar nos autos, foi utilizada pela testemunha até o final do seu relato.

Quando há mais de uma testemunha, pode-se perceber que o interrogador tende a sugerir respostas para as testemunhas que inquire em segundo plano, incluindo os dados obtidos no interrogatório da primeira. Dessa forma, tendo dois relatos idênticos que incriminam o réu, parece ser mais fácil julgar e se convencer de que a decisão foi justa. A impressão que se teve durante o trabalho de campo é que juízes e promotores preferem relatos uniformes que não divirjam, estimulando respostas por meio de gestos afirmativos com a cabeça e com o olhar, no sentido de que as testemunhas "estão indo bem". Este fato sugere que pouco ou nada importam as nuances narrativas dos testemunhos, mas sim uma verdade que já está definida.

Todavia, a testemunha pode não corresponder às expectativas do interrogador, se tiver algo a esconder ou se apresentar um comportamento hesitante ao responder às perguntas propostas, o que pode mudar a sua identidade mediante o espaço do testemunho. Isso se mostrou claro quando, noutra audiência criminal, uma testemunha, questionada e pressionada, acabou por confessar participação no crime investigado. A partir desse momento, ela deixou de ser tratada como testemunha para ser tratada como réu. O interrogador precisou "puxar do sistema" todo seu histórico criminal, o que foi suficiente para aceitar aquela confissão como verdadeira e o MP se pronunciar dizendo que tomaria as medidas cabíveis. 
No contato com as nuances das audiências também foi possível perceber que os juízes, ao se colocarem nas posições do campo, também o produzem. Por exemplo, eles têm uma tendência a acreditar que o crime é alheio a ele e que somente o réu é mau. Réu, esse que habita outro universo, que ele, o juiz, nunca habitará porque nunca apresentará nada do réu em si. Ele, o oposto do réu, é o bem, e existe para fazer a justiça. Esta é a eficácia requerida e que se inicia pela enunciação das posições em um espaço ritual distinto (BOURDIEU, 1986).

O juiz é, portanto, a "justiça encarnada". Ele se identifica com a dualidade "bem e mal" e com as formas de ritualização: a toga (máscara de ação e de proclamação da decisão), a disposição das pessoas na sala e as algemas. Tais elementos ritualísticos vão além do mundo ordinário porque criam um espaço reduzido da vida que pode ser controlado por uma gramática jurídica específica (LOPES, 2010).

O juramento não é o único detalhe ritual que compõe a audiência. Existe a toga, que permite a socialização da violência discursiva que vem de fora, mas que é exercida de forma legítima, vez que é um escudo protetor (LOPES, 2010) capaz até de gerar um sentimento de superioridade em relação às partes. Se a violência do crime desestabilizou a sociedade, cabe ao ritual determinar qual a violência correta a ser seguida: a violência simbólica pura e legítima, autorizada pelo ritual. A toga pode proteger a ação violenta simbólica de "qualquer conluio com o criminoso e de qualquer confusão com o crime" (GARAPON, 1997, p. 85).

Para Lopes (2010), a toga é a marca da superioridade da instituição sobre o homem, pois permite o refúgio na generalidade da função, impessoalizando a decisão sob o pretexto de que "é injusto, mas é a lei", porque da boca da toga sai o discurso que se convencionou verdadeiro: a verdade institucional. Garapon (1997) identifica uso da toga como o mais antigo uso civil ainda em vigor. O grande número de botões representa a vontade de ocultar a maior parte do corpo: quando o magistrado abotoa a toga, fecha o seu corpo numa série de compulsão da dúvida.

A história da toga confunde-se com a história da própria atividade judiciária, tendo servido inicialmente para distinguir a nova categoria de letrados, na qual a monarquia se apoiava para afirmar o seu poder em detrimento do feudalismo. Atualmente, apenas os 
magistrados continuam a usar uma vestimenta velha de mais de dois mil anos e que sofreu alterações consideráveis, mas cujo corte e cuja cor permanecem idênticos (GARAPON, 1997).

O desfecho da audiência se dá com a oitiva do acusado. Um arguido quando entra numa sala de audiência sente o mesmo que um ator ao subir no palco: "toda gente está ali, talvez a família, os amigos, mas não há tempo para ver ninguém. O arguido é acometido pelo medo da mesma forma que o actor sente o medo do palco" (GARAPON, 1997, p. 50).

Em uma audiência criminal, antes da chamada do réu, o magistrado se dirigiu à pesquisadora com certo desconforto e explicou que o acusado ficaria algemado, devido à sua periculosidade. Não se afirma que o magistrado goste que os "seus" réus usem algemas, mas como sempre o réu é o outro, o mal e mau, pode suportar mais esse encargo. O sistema penal divide a sociedade entre bons e maus e, consequentemente, se fortalece e se retroalimenta com a concentração do poder punitivo (ZAFFARONI, 1991).

Quanto à "periculosidade", naquela ocasião, um policial armado permaneceu junto ao réu durante todo o tempo em que este depôs, mas pode-se dizer que ele não apresentava nenhum grau de periculosidade: estava desarmado, de chinelos, cabeça raspada e com farda azul de presídio.

Ao observar o comportamento do policial, foi possível identificar que ele desempenhou seu papel de diferentes formas. Apresentou algum grau de companheirismo com o réu, ao mesmo tempo em que era grosseiro com a sua família e submisso às ordens do juiz. Isso exemplifica as diversas relações de poder que podem ser observadas nos segundos que marcam o espaço do testemunho. As posições no campo reforçam a eficácia mesma dessas posições alimentando e sendo alimentada pelos diferentes habitus ali dispostos (BOURDIEU, 1989).

A propósito, a esposa de um dos réus entrou na sala quando a audiência já havia começado e ouviu uma fala extremamente ríspida do policial no sentido de que ela deveria pedir permissão para entrar e que era falta de respeito abrir a porta daquele jeito. Em que pese o magistrado não ter se importado com a atitude da esposa do réu, também não reprimiu a ação grosseira do policial, dando por certa sua atitude. Na mesma linha, são 
criados estereótipos de policiais que devem extinguir o mal e juízes que não precisam criticar o sistema para que ele continue credível e se mantenha (ZAFFARONI, 1991).

Ao mesmo tempo, o mesmo policial trocou frases e risos com o réu, indicando uma possível convivência amigável, talvez por interagirem bastante no presídio, retratando a habitualidade dos policiais darem conselhos e sugestões confidenciais que suscitam a boa disposição dos juízes (GARAPON, 1997). O policial se vale da sua experiência no ritual e dá dicas, uma espécie de ajuda ao réu, tendo em vista o possível grau de proximidade entre ambos, bem como o bom andamento ritualístico, denotando que sabem que as formalidades não os atingem em um determinado ponto e também porque controlam a parte da ritualística a eles relacionada.

\section{OS ATORES E O RITUAL DE INTERAÇÃO ATRAVÉS DA LENTE DE EVRING GOFFMAN}

Erving Goffman (2010) foi um pesquisador que tomou como matéria de suas pesquisas a vida cotidiana e suas formas de interação. Em sua abordagem, não temos os macromodelos sociológicos de explicação, tais como o Estado, a Economia, a Família, etc., mas, tão somente, os atores em sua infinita arte de representar no grande teatro da vida.

Uns dos objetivos de Goffman ao escrever sobre o ritual de interação foi tentar descobrir a ordem normativa e comportamental encontrada nos lugares povoados, quais seriam as regras de uma determinada ocasião social, bem como a construção da coerção num ambiente rotinizado. Trazer essas análises para o estudo em questão é de grande valia, porque os interrogatórios das audiências judiciais são grandes rituais de interação, cuja manutenção da fachada e da representação do "eu" e cujo cumprimento das regras de observância obrigatória são fundamentais para o equilíbrio ritualístico.

Movimentos faciais numa conversa entre duas pessoas ou comportamentos esperados em conferências e numa audiência judicial: cada ocasião social tem suas características interacionais peculiares, mas que apresentam as mesmas unidades naturais de interação. Cada ocasião possui um ethos, uma estrutura emocional própria (GOFFMAN, 2010) que é criada e reproduzida pelos indivíduos que as realizam, ou seja, há tons específicos de comportamentos para cada interação social. 
As regras dessas interações são implícitas, porém muito claras e determinam o que é proibido e o que é permitido para os indivíduos numa ocasião social; são regras que não se referem somente às formas de convivência social aplicadas igualmente a todos, mas também têm relação com os papéis e cargos sociais ocupados. Assim, ofício e status profissional são ensejadores de pistas para se determinar quais regras devem ser seguidas em uma interação entre atores.

A título de exemplo, pode-se citar os crimes de desacato e de falso testemunho que, antes de estarem previstos em lei, têm forte relação com os papéis e cargos sociais dos atores/vítimas (funcionários públicos), que subordinam os demais (cidadão, réu, testemunha). Há regras impostas que pairam sobre a relação entre a pessoa do funcionário público (juiz, servidor, promotor) e a pessoa do cidadão (réu, testemunha, eleitor). A Justiça tolera menos as infrações ao ritual do que os delitos de direito comum. Contrariamente, quem não segue essas normas sociais de civilidade é encarcerado ou internado, pois não respeita e não se orgulha das regras das ocasiões sociais (GARAPON, 1997).

No tópico antecedente foi elucidada a forma como o juiz fala, a sua formalidade, a toga, bem como a sua relação com os demais atores. Também já se descreveu as salas de audiências e a disposição dos atores. Através da lente Goffman, pode-se aplicar os estudos da fachada e das interações aos casos reais observados já apresentados.

A questão da interação entre os atores nos remete à análise da fachada, que precisa da interação com o outro para fluir e que se expressa a depender da arte do encontro, por isso ela se localiza no fluxo das interações e não dentro do eu. A ação só "é" porque é vista/dividida, então aqui ação é interação. A fachada é um valor social positivo que uma pessoa reivindica para si por meio da linha que os outros pressupõem que ela assumiu durante um contato, é a imagem do eu delineada em termos de atributos sociais aprovados. "Nossa fachada, então, é uma coisa sagrada, e a ordem expressiva necessária para mantê-la é, portanto, uma ordem ritual" (GOFFMAN, 2011, p. 26).

Para manter uma fachada é preciso levar em consideração o seu lugar no mundo social. A pessoa está com a fachada quando a linha desenvolvida por ela é confirmada pelos outros participantes. Diz-se linha aquele padrão de atos verbais através do qual uma 
pessoa expressa sua opinião sobre a situação, sobre os participantes da interação e sobre ela própria. A fachada não é o objetivo de uma interação, mas uma condição desta. A forma como se fala, como se olha e os argumentos que se utiliza podem ser indicadores do lado que se está, do poder que se tem e do que deve ser feito. Tudo isso faz parte de uma fachada.

Se a pessoa sente que está com a fachada, sente-se confiante. Se os outros percebem que ela está com a fachada errada e disfarçam, ela continua se sentindo confiante; mas se ela percebe que está com a fachada errada, sente-se envergonhada. 0 juiz que tranca a porta da sala de audiência é temido e mantém a mesma linha em todos os momentos da sua atuação (se faz temer sempre); ele está com a fachada e se sente confiante até mesmo para intimidar os demais atores, que sustentam essa atitude com palavras, gestos ou simplesmente toleram a atuação do juiz. Nesse sentido, quanto mais poder e prestígio se tem, mais provável que os outros demonstrem consideração com seus sentimentos (GOFFMAN, 2011) como, por exemplo, aceitar a porta fechada.

Numa interação, o respeito próprio e a regra de consideração são esperados, pois cada um teria um "direito" de desempenhar a linha escolhida. O olhar é a principal forma de abertura para um engajamento, é como se fosse um estado que todos temporariamente aceitam a linha de todos os outros. Uma forma de sempre estar com a fachada correta é utilizar meios que disfarçam a vulnerabilidade, que é inerente às pessoas. A título de exemplo, tem-se a toga do juiz apoiada na rispidez que o faz ser reconhecido pelos demais como a própria justiça; aqui o público reconhece na sua toga as insígnias da sua função (GARAPON, 1997, p. 116).

O advogado também legitima o ritual, trazendo a sensação de contraditório, da mesma forma que o próprio ritual o investe de imprescindibilidade, elevando-o ao grau de função essencial à justiça e é "essa a permuta simbólica do ritual, o qual institui uma legitimação recíproca" (GARAPON, 1997, p. 101).

O Ministério Público representa seu papel de comprometimento com a eficácia, investigando ou emitindo pareceres, "propondo a solução que tomaria se tivesse assento no tribunal" (GARAPON, 1997, p. 99) e dessa forma atua cada vez mais ativamente para 
tentar retribuir a esperança e os anseios de justiça e de super-herói que Ihe foram atribuídos por certos grupos sociais, sobretudo pela influência da criminologia midiática.

No que tange às testemunhas, são rapidamente correspondidas as que esperam que o magistrado ou o promotor demonstrem como elas devem agir, caracterizando a tentativa de descoberta de que tipo de linha os outros estão dispostos a apoiar para as outras pessoas, conforme descrito em Goffman (2011). No caso evidenciado no tópico anterior, o promotor esperava que as testemunhas colaborassem com o andamento processual, transmitindo sinais positivos com a cabeça no sentido que ela estava indo bem com os depoimentos, o que só ocorreu porque a testemunha ou demandou ou acatou tal medida.

Quanto aos acusados, é-lhes imposto comportamento condizente com as formalidades do Fórum. São formalidades desconhecidas e que geram inquietação, pois não se sabe a hora certa de entrar na sala, de falar muito ou pouco, de ficar em silêncio. 0 trânsito do acusado na sala de audiências não é livre, só podendo entrar nesse espaço quando o magistrado mandar que lhe conduzam à sala. Não lhe é permitido conversar nem questionar a demora da sessão, que geralmente atrasa. Uma vez dentro da sala de audiências, é-Ihe obrigatório aguardar que o juiz e o Ministério Público terminem o diálogo, caso estejam conversando, independentemente do assunto.

O acusado deve, portanto, responder ao magistrado exatamente como este lhe perguntou: se foi uma pergunta de "sim ou não", deve dizer "sim" ou "não" sob pena de ser repreendido. De outra parte, se foi uma pergunta discursiva, ele precisa discorrer sobre o assunto, sob pena de ser novamente repreendido.

Alguns papéis são esperados para o réu: o papel de rude, tímido, mal-humorado, pouco acessível, primário, de poucas palavras, enfim, o perfeito retrato de um marginal tal como o grupo social espera vê-lo. Tal comportamento é provocado justamente pela inquietação da sensação do desconhecido que a formalidade do Fórum Ihe causa (GARAPON, 1997). Em especial ao papel de acusado que quer se "redimir", pode-se dizer que causa certo gozo para os magistrados, pois a submissão à ordem ritual e a culpabilidade que o réu suscita atribuem-lhe o papel esperado e desejado, podendo o magistrado, inclusive, exercer o paternalismo advindo pela manipulação da sua imagem (ZAFFARONI, 1991). 
É preciso responder educadamente às questões do juiz, pois o comportamento do réu também será considerado quando da prolação da sentença. De outra parte, desde o início da inquirição, o juiz pode utilizar expressões difíceis de serem compreendidas pelo acusado, inclusive para reafirmar a sua inferioridade. E é neste ponto que reside a violência simbólica do processo penal, pois realiza-se a reconstrução do espaço social à custa do acusado, que não sabe que comportamento deve manter, nem sabe identificar se foi condenado por este comportamento ou pelo delito pura e simplesmente (GARAPON, 1997).

Pode-se trazer a questão da impureza e da sujidade para analisar o ator/réu, quando se parte da premissa de que é impuro tudo aquilo que não está no seu lugar (sapatos na mesa ou talheres com comida na cama), tornando o réu impuro por estar em desacordo com regras do ritual, à margem dessa ritualística mágica dominada por todos os presentes. Não impuro nele mesmo, mas como o réu está em desconformidade com o ambiente, fazse estranho à audiência, portanto o seu lugar é fora dela, o que o torna relativamente sujo.

As ocasiões de fala, mesmo as mais triviais, exigem que cada participante demonstre certa preocupação de como lidar consigo e com os outros participantes, o que vale sobretudo para o réu. Em uma audiência foi possível perceber que o réu estava mantendo um comportamento classificado pelo magistrado como "debochado demais", sendo retaliado: "você está debochando? Porque não fala direito?". Dessa forma, o juiz ordenou que o réu inspirasse a postura esperada, se defendendo ou demonstrando culpa, vedando o deboche.

Juízes, advogados, espectadores, acusados e partes envolvidas estão, graças à presença simbólica, sob a influência do poder do elemento englobante, da ordem ou da natureza, sob a influência do direito (GARAPON, 1997). Em suma, o desempenho dos papéis pelos atores do ritual judiciário faz referência ao eu como uma imagem montada a partir das implicações expressivas do fluxo total de eventos numa ocasião; e do eu como um tipo de jogador num jogo ritual que lida honrada ou desonradamente, diplomaticamente ou não, com as contingências dos juízos na situação (GOFFMAN, 2011).

O respeito à fachada alheia é de cunho prático e não real. Trata-se de juízos de boca pra fora e não de acordos sinceros, pois um precisa que o outro respeite a sua fachada, então respeita a do outro, justamente para conservar os encontros e as relações sociais. 
Não se trata de altruísmo, mas de se esperar o mesmo em troca. Assim, defende-se não só a própria fachada, mas as dos outros, para que haja tal retribuição (GOFFMAN, 2011).

Observou-se uma autoridade judiciária que era conivente com as saídas antecipadas do seu servidor em troca de elogios à sua pessoa na presença dos demais funcionários e autoridades. Dessa forma, pode-se exemplificar com um dado concreto que os papéis do juiz, promotor, oficial de justiça e policial por vezes são complementares e se apoiam uns nos outros para subsistirem, uma vez que defendem suas fachadas reciprocamente.

Goffman (2011), ao expor sobre a noblesse oblige, afirma que pessoas em posições altas, além de preservarem a sua fachada, preservam a fachada alheia, oferecendo ajuda que geralmente são aceitas, mesmo que o destinatário não precise dela. Ele exemplifica dizendo que é difícil se recusar uma ajuda, ou mesmo um aperto de mão, quando se é deficiente.

A recuperação de memórias sobre a atividade profissional perante algumas Varas possibilitou a identificação de um magistrado paternalista que atuava de forma mais moral do que jurídica diante da "reincidência" do adolescente. Naquela ocasião, mesmo tendo recebido a "tão boa ajuda" do juiz em forma de prestação de serviços à comunidade, "esnobou" a grande chance de se regenerar; como se não aceitasse a ajuda do magistrado. $\mathrm{Na}$ segunda infração, então, o magistrado aplicou-lhe a medida socioeducativa de internação. Trata-se de uma ação que tentou combater a ideia veiculada pelos meios de comunicação de que os "menores" são impunes (ZAFFARONI, 1991).

Por meio dos gestos do estado de fala durante um ritual pode-se perceber muitos aspectos que ficariam ocultos caso essa observação não ocorresse; os eventos poderiam ser considerados como não intencionais, ao acaso. Percebemos se uma conversa com uma pessoa é possível, percebemos se alguém é bem-vindo numa conversa que já foi iniciada (GOFFMAN, 2011), identificamos qual a linha a ser mantida e quais as relações de poder existentes naquela interação: tudo por conta dessas minúcias circunscritas no ritual de interação "audiência judicial". 


\section{PODER SIMBÓLICO, O DIREITO E AS RELAÇÕES DE FORÇA NAS AUDIÊNCIAS}

Diversas relações de poder podem ser percebidas num interrogatório, desde o poder institucional até o poder entre os atores. Ao longo deste estudo observacional de campo, relações de poder foram percebidas e serão discutidas, cabendo antes uma pequena análise do que seria esse "poder".

O poder é difuso e não localizável por natureza, é uma relação de forças, assim como qualquer relação de forças pode ser uma relação de poder. O poder não é objetivável, não é um algo, uma coisa passível de ser apropriada. (HENRIQUES, 2010).

O poder é mais do que possuir, o poder é exercer, logo, não pertencente a uma determinada classe, porque não pode ser de ninguém e também não é um "pacote valioso" que se guarda dentro do cofre. O poder não é posse nem propriedade das elites e não é visto como um direito conquistado, exortado através da força e exercido de cima para baixo por um conjunto de pessoas privilegiadas (HENRIQUES, 2010).

Dessa forma, não se pode afirmar que o Estado tem o poder porque instituiu o inquérito, nem que o juiz tem todo o poder sobre o acusado, nem que o acusado carece de poder porque é esmagado pelo sistema. Torna-se mais claro vislumbrar o poder como um conjunto infinito de sistemas de vetores que podem mudar de direção, de intensidade e até mesmo de sistema.

Por isso o poder não é uma qualidade ou particularidade daqueles que o exercem. Se assim fosse, os dominantes sempre carregariam essa marca e os dominados não possuiriam essa distinção, logo, “o poder não tem essência, é operatório, é relação". E a relação de poder é o conjunto das relações de forças que passa tanto pelas forças dominadas, como pelas dominantes (HENRIQUES, 2010, p. 94).

Em termos de audiência judicial, entre o Estado e o cidadão pode ser estabelecida uma relação de poder quando a organização autoritária do real se dá através de uma linguagem tipicamente jurídica não dominada pelo réu ou pelas testemunhas. O poder é tão teatral quanto institucional: o fausto, o aparato, as cerimônias, os ritos e a solenidade correspondem a outros tantos instrumentos do prestígio e da permanência do poder (GARAPON, 1997). 
Noutro patamar, hipoteticamente, a mesma juíza que determina com gozo a prisão de um acusado pode ser destinatária de um olhar constrangedor tipicamente machista deste mesmo acusado, perfazendo assim, duas relações de forças entre duas pessoas quase que simultaneamente. O policial é subordinado ao juiz, demonstrando excesso de submissão, enquanto que, ao mesmo tempo, humilha a esposa do acusado que entrou na sala de audiência de forma incompatível com o ritual.

O magistrado impõe a sua vontade a todos os presentes na audiência (inclusive ao MP), portanto é o dominante nesta relação de poder. Essa hierarquia também é comum fora das audiências pois o juiz, usuário constante da toga, é detentor de capital social e confortavelmente impõe seu status às demais pessoas, reivindicando, por exemplo, que a justiça obrigue os funcionários do seu prédio a chamá-lo de "senhor" ou "doutor".

Enfim, o poder não é uma instituição ou uma estrutura, nem certa potência de que alguns seriam dotados; é o nome que se dá a uma situação estratégica complexa numa sociedade determinada (FOUCAULT, 1976) e que também produz verdade. O ritual judiciário reforça a ideia de uma ordem jurídica impermeável às influências sociais quando ela não é mais do que uma pressão suplementar da classe dominante. Isso nos remete ao poder simbólico: um poder invisível que só pode ser exercido com a cumplicidade daqueles que não querem saber que lhe estão sujeitos ou mesmo que o exercem. O poder simbólico é um poder de construção da realidade que tende a estabelecer uma ordem gnoseológica, o sentido imediato do mundo, em particular do mundo social (BOURDIEU, 1989).

E o ritual judiciário, como espaço, procura a distância entre os sujeitos dominantes e dominados, entre patrão e operário, proprietário e locatário, marido e mulher, filho e progenitor. O rito separa, impõe a distância, mas põe todos no mesmo comprimento de onda (GARAPON, 1997). A separação se dá tanto pela disposição geométrica, quanto pelos discursos, ambos legítimos, apesar de contraditórios, daí Garapon afirmar que o discurso jurídico permite operações que a razão por si só não conseguiria realizar.

Por exemplo, uma decisão com base em discursos "legítimos, porém antagônicos": a decisão nasce com o poder de ser imposta, configurando-se em uma violência simbólica legítima, pois que dotada de um saber não disponível aos profanos. Nas palavras de Bourdieu (1989), isso seria impor a apreensão da ordem estabelecida como natural por 
meio da imposição mascarada de sistemas de classificação e de estruturas mentais objetivamente ajustadas às estruturas sociais e tal efeito ideológico consiste na imposição de sistemas de classificação políticos aparentemente legítimos, mas que não passam de taxonomias filosóficas, religiosas e jurídicas.

Pierre Bourdieu (2008) aponta uma discordância estrutural referente à própria língua portuguesa, por exemplo, quando uma mesma palavra significa uma coisa no mundo vulgar e outra coisa no mundo jurídico, tornando difícil o trânsito livre entre esses dois mundos, a saber, a palavra "causa", o que reflete o primeiro passo para adentrar o espaço jurídico, que é dominar e se reconhecer nesse vocabulário peculiar.

É perceptível, segundo o autor, o reflexo direto das relações de forças no discurso jurídico, que é um instrumento de dominação dos interesses dos dominantes: as práticas e os discursos jurídicos são produtos do funcionamento de um campo. As relações de força conferem a estrutura desse campo e a lógica interna das obras jurídicas delimita o universo das próprias soluções jurídicas.

Quando Bourdieu (2008) introduz o tema "o monopólio de dizer o direito", aduz haver a concorrência por esse monopólio, que reside na seletividade, ou seja, somente podem interpretar o corpus jurídico aqueles agentes com competência social e técnica, pois eles e apenas eles têm uma visão legítima e justa do mundo social. Sem dúvida, essa é mais uma forma de se reafirmar a necessidade do ritual, já que tais técnicos jurídicos são os que realmente sabem geri-lo.

Tudo o que foi exposto não constitui uma máscara ideológica, mas sim, a expressão do funcionamento do campo jurídico que se torna indispensável aos agentes que vivem da venda de bens e serviços jurídicos (BOURDIEU, 2008). Para o sociólogo, nada é menos natural do que a necessidade jurídica, do que a necessidade de se procurar serviços jurídicos por conta de uma injustiça, até porque o sentimento de injustiça varia de acordo com a posição social; o senso de justiça é uma construção social. São gerados problemas e apresentadas soluções segundo uma lógica totalmente hermética e inacessível aos profanos, que não sabem interpretar os códigos e as normas.

O ritual que o direito construiu, então, é um "sistema simbólico" e a forma específica do discurso e das peculiaridades que perfazem os ritos é capaz de produzir e 
reproduzir determinados pensamentos, práticas e procedimentos que tornam o universo jurídico um verdadeiro universo autônomo, com lógica própria e um modo específico de funcionamento. Na visão de Garapon (1997), essas cerimônias e rituais mostram que a profissão judiciária não é uma profissão como as outras: mais do que uma profissão, tratase de um estado.

\section{O INTERROGATÓRIO COMO DEGRAU PARA A VERDADE E ILEGITIMIDADE DO SISTEMA PENAL}

Mais do que um provedor de ritual, o direito é um espaço de conflito que se desenrola de forma institucionalizada, seguindo determinados procedimentos que são comuns às partes do jogo. "Entrar no domínio do direito significa matar o assassino, mas matá-lo segundo certas regras, certas formas" (FOUCAULT, 2002, p. 57).

Assim, o direito se apresenta como a manifestação institucionalizada da guerra: não de uma batalha sangrenta, mas de procedimentos, argumentos e fatos. Enquanto na guerra o vencedor é aquele que sobrevive às batalhas, no direito vence aquele que teve a sua verdade aceita por um mediador.

E é através do inquérito que as duas verdades são confrontadas, segundo um procedimento institucionalizado e regulamentado. A conclusão do inquérito funciona como um poder-saber, pois determina a verdade que prevaleceu no embate: é poder porque impõe coercitivamente essa verdade e é um saber porque fruto de um embate de verdades.

Foucault (2002) nos apresenta uma hipótese do nascimento do inquérito que passa pelas lutas na Grécia, resultando na elaboração de uma determinada forma de descoberta judiciária da verdade que renasce na Idade Média. Se antes havia no direito feudal o sistema da prova, a partir da segunda metade da Idade Média as velhas práticas judiciárias se transformaram em novas formas de justiça e de procedimentos judiciários.

O que foi inventado diz menos ao conteúdo e mais às formas e condições de possibilidade do saber. O direito de ordenar e controlar a prolação da verdade, que geralmente tratava da circulação de bens, foi confiscado pelos mais ricos e mais poderosos. Os indivíduos não mais poderiam resolver as suas questões de forma privada, precisando levar o caso a um poder exterior, o "procurador", que surge ineditamente e se apresenta 
como representante do soberano, rei ou senhor. Ele dubla e substitui a vítima, o que permite que o poder político se aposse do procedimento judiciário.

Da mesma forma, nasce a noção de infração, abrangendo a ofensa ao Estado que, consequentemente, poderia exigir a reparação através das penas de multa (confiscações). Para saber se alguém era culpado ou não, não bastava mais o mecanismo da prova, da luta entre dois adversários em pé de igualdade, era necessário terceiro, o mediador que, por meio do inquérito, decidia e prolatava a verdade.

Mais do que um ritual que hoje se mostra indispensável para os atores jurídicos, o inquérito se apresenta também como uma forma de dominação, de poder-saber, uma vez que através dele "descobre-se a verdade".

O inquérito é uma forma política, uma forma de gestão, de exercício de poder que integra o sistema penal por meio da instituição judiciária. O inquérito veio a ser uma maneira, na cultura ocidental, de autentificar a verdade, de adquirir coisas que vão ser consideradas como verdadeiras e de as transmitir. $O$ inquérito é uma forma de poder-saber e a análise dessas formas que nos deve conduzir à análise mais estrita das relações entre os conflitos de conhecimento e as determinações econômico-políticas (FOUCAULT, 2002).

O testemunho compreende-se como uma das fases do inquérito, constrangido por forças que já lhe conferem um lugar discursivo esperado, ritualizado e disciplinado. Para Zaffaroni (1991), o discurso é formalista porque desconectado das relações de poder e o controle jurídico-penal é ilegítimo porque produzido via esse discurso, estando sua construção teórica em desconformidade com a experiência prática.

Trata-se de um saber criminológico advindo de um sistema desigual que se ocupa em identificar as ações das pessoas criminalizadas pelo sistema penal. O discurso penal se distancia, assim, do processo real de criminalização, uma vez que o mesmo sistema poderia escolher arbitrariamente as condutas puníveis e as regras a serem seguidas (ZAFFARONI, 1991).

As características estruturais do sistema penal, segundo Zaffaroni (1991), são incompatíveis com a defesa dos direitos humanos, pelo que sugere uma proposta inicial de superação do sistema baseada em algumas intervenções no modelo vigente. Assim, considera a viabilidade instrumental do minimalismo penal a curto prazo, constituindo um 
meio para o alcance do abolicionismo penal. A resposta ao descrédito do sistema punitivo, o realismo marginal, abrange duas dimensões: a criminológica e a jurídico-penal. A primeira diminuiria a violência do sistema e suprimiria o próprio sistema, enquanto que na segunda, as agências executivas decidiriam com base em princípios redutores de violência.

A instrumentalização da proposta envolve a introdução de um discurso diferente e não violento, assim como a neutralização das propagandas a favor do sistema que são veiculadas nos meios de comunicação, para que não dotem de estigma os diversos atores do sistema penal e os grupos pertencentes às classes menos favorecidas da população que figuram geralmente como réus.

\section{CONSIDERAÇÕES FINAIS}

Para Lima, o sistema judicial brasileiro nos apresenta um mosaico de "sistemas de verdade", tanto em suas disposições constitucionais, como em suas disposições judiciárias e policiais que, sem mencionar a vida vicinal de algumas normas, estão reguladas por um sistema hierárquico e excludente. Sistema que permite que estas diferentes lógicas sejam usadas alternativa e alternadamente, embora as verdades por elas produzidas se desqualifiquem umas às outras, o que redunda em verdadeira "dissonância cognitiva", tanto para os operadores do sistema como para a população em geral (LIMA, 1997).

Em termos da vida hermética dos sistemas inquisitoriais, as interações e concessões mútuas das fachadas desempenhadas pelos atores do ritual judiciário contribuem para a consagração dos termos rebuscados, da toga, dos termos latinos e do uso recorrente do título de "doutor" entre pares e profanos. Desempenhar tais fachadas permite que o mundo jurídico flua, que ele afinal aconteça como o esperado e que as pessoas se sintam seguras e confiantes naquela cena e que perpetuamente ajam da mesma forma, possibilitando a percepção das relações de poder que podem surgir dessas interações, à medida que interrogatório pode ser considerado uma forma de se dizer a verdade.

Nesse sentido, a verdade do inquérito se compara a uma série de encaixes de partes que se ajustam umas às outras e, para que todas estas metades e metades de metades possam ajustar-se umas às outras, é necessário adaptar-se e encaixar-se para se reconstituir o perfil total da história (FOUCAULT, 2002). E esse ajuste entre metades se dá, 
como buscamos demonstrar, de forma ritualística, ocultando um poder-saber sob o regime de verdade, pois determina e impõe coercitivamente a verdade a partir da estruturação do mundo circunscrito ao âmbito judiciário. As normas desse mundo são sentidas e vividas como obrigatórias. Abdicar delas é se colocar fora do mundo da verdade jurídica: organizado, hierarquizado e desinteressado como a lei e sentido pelos agentes como algo natural.

\section{REFERÊNCIAS}

BOURDIEU, Pierre. Razões Práticas: sobre a teoria da ação. São Paulo: Papirus Editora, 2008. BOURDIEU. O poder simbólico. Rio de Janeiro: Bertrand Brasil, 1989.

BOURDIEU. La force du droit: éléments pour une sociologie du champ juridique. Actes de la Recherche en Sciences Sociales, v. 1, n. 64, p. 3-19, 1986.

FOUCAULT, Michel. A verdade e as forma jurídicas. Rio de Janeiro: NAU Editora, 2002.

GARAPON, Antoine. Bem julgar: ensaio sobre o ritual judiciário. São Paulo: Instituto Piaget, 1997.

GEERTZ, Clifford. A Interpretação das culturas. LTC: Rio de Janeiro, 2014.

GOFFMAN, Evring. Ritual de interação: Ensaios sobre o comportamento face a face. Rio de Janeiro: Vozes, 2011.

GOFFMAN, Evring. Comportamento em lugares públicos. Rio de Janeiro: Vozes, 2010.

HENRIQUES. R. S. P. Poder e Resistência: o estado e as rádios pirata. Radio Leituras, Rio Grande do Sul, ano I, n. 1, jul./dez. 2010. Disponível em: <http://radioleituras.files.wordpress.com/2010/12/radioleituras51.pdf>. Acesso em: 15 maio 2018.

LIMA, Roberto Kant. Ensaios de antropologia e de direito. Rio de Janeiro: Lumen Juris. 2007.

LIMA, Roberto Kant. Polícia e exclusão na cultura judiciária. Tempo Social (Revista de Sociologia da USP), v. 9, n. 1, p. 169-183, 1997.

LOPES JR., Aury. Direito processual penal e sua conformidade constitucional. Vol.1. Rio de Janeiro: Lumen Juris, 2010.

MISSE, Michel. O Papel do Inquérito Policial no Processo de Incriminação no Brasil: algumas reflexões a partir de uma pesquisa. Revista Sociedade e Estado, v. 26, n. 1, 2011. 
SILVA, Sandro José da. "Vou falar a verdade": a produção das identidades sociais nos contextos de Audiências Públicas. Confluências: Revista interdisciplinar de Sociologia e Direito, Rio de janeiro, v. 15, n. 2, p. 154-178, 2013. Disponível em: <http://www.confluencias.uff.br/index.php/confluencias/article/view/323>. Acesso em: 15 maio 18.

TURNER, Victor. La selva de los símbolos. Madrid: Siglo XXI, 1980.

ZAFFARONI, Eugênio Raúl. Em busca das penas perdidas: a perda de legitimidade do sistema penal. Rio de Janeiro: Revan, 1991.

HENRIQUES, Catarina Gordiano Paes; SILVA, Sandro José da. Rito e testemunho na produção da verdade jurídica. RBSD - Revista Brasileira de Sociologia do Direito, v. 6, n. 1, p. 3-26, jan./abr. 2019. 